\title{
園芸療法の紹介
}

\section{Introduction to Horticultural Therapy}

長谷川真人 1$)$

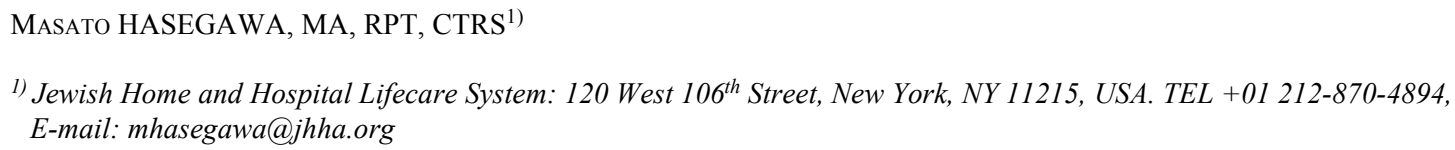

Rigakuryoho Kagaku 22(2): 301-304, 2007. Submitted Dec. 5, 2006.

ABSTRACT: This paper will examine the concept and services of Horticultural Therapy (HT). Also, the clinical programs, the case studies, and the research of HT will be discussed.

Key words: Horticultural Therapy, Outcomes

要旨 : 園芸療法についての, 一般的な定義, 実践方法, 治療効果の説明をし, 更に理解を深めるために具体的な園芸 療法の例として，実施されているプログラムと事例と最近の研究についても説明する。

キーワード : 園芸療法, 治療効果

受付日 2006年12月5日

\section{I.はじめに}

“癒し”という言葉が世間一般で, 頻繁に使われる ようになったが，私達は，植物との関わり通して， 癒されていることが多くある。まず基本的な事実と して, 私達が活動することができるのは, 植物の光 合成により産出された酸素を摂取しているからであ る。また, 森林浴を通して, 人閒が心身ともにリラッ クスできる現象は, 周知の事実である。植物から得 られる数々の恩恵は人間にとって不可欠なものであ るが, その恩恵を様々な形で応用する, 園芸療法
（Horticultural Therapy：HT）が欧米で発達してきた。 筆者は, 現在, 米国にて, Certified Therapeutic Recreation Specialist（CTRS）として, 様々な治療の場面で, 園 芸療法的なアプローチを実施している。本稿では, 米国における園芸療法の基本概念を説明し，実際の 臨床現場での園芸療法の応用方法を紹介していく。

\section{II. 園芸療法とは}

American Horticultural Therapy Association (AHTA) は, 園芸療法を「限定的な治療ゴールに達するため 
に, 訓練されたセラピストによる, 園芸に関連した活 動の実施」1) と定義している。米国において, 庭園での 園芸活動などを精神病の治療として応用したのは, 300 年以上前からだとされている2)。現在では, 園芸療法 は, 一般病院, 精神病院, リハビリテーションセンター, 介護施設（Nursing Home），ディケアセンター，職業訓 練所, 学校, 更正施設, 一般地域植物園や庭園などで 応用されている。AHTAにおいて, 園芸療法士として認 定されるための細かい教育ガイドラインが設定されて いるが，実際には，園芸療法士に限らず，CTRS，作業 療法士, 理学療法士, 看護師, 専門ボランティアなど 園芸療法に関する一定の知識を持った様々な専門職に より, 園芸療法は実施されている。大学や専門学校な ぞ, 様々な教育機関で園芸療法についての講習が行わ れている。Bronx Botanical Gardenが実施している園芸療 法の講習は, 基本的な植物や温室の管理方法や人間行 動分析法, バリアフリーの庭園の設計方法, 身体, 精 神面などの各種障害に対する限定的な園芸療法の方法 論等の内容となっている3)。

\section{III. 園芸療法の実施手順}

園芸療法を実施する手順を以下に紹介する。

\section{1. 限定的な園芸療法の選択}

園芸療法といっても様々な介入方法が有り, どの介 入方法を選択寸るかにより,その後の手順が変わってく る。介入方法として, 植物の手入れ（例，刈り込み，繁 殖, 水遣り, 土袞の手入れ）植物を使った芸術活動（例, フラワーアレンジメント, 押し花作り), 植物園の管理, 植物園の訪問, 植物に関するディスカッション, 料理な ぞが挙げられる4)。

2. 施設, 植物, 用具の準備

園芸療法を行う施設と場所の選出（例，植物園の利 用, 温室の利用, 庭園の利用, 作業室の利用など), ど のような植物を使うか, どのような用具を必要とする かを考慮する。植物園や庭園にて, 園芸療法を行う際 には, 環境的な要因（例, 庭園が車椅子がアクセスで きるように工夫して設計されているかなど）を十分に 考慮する。

3. 患者のアセスメント

一番最初の治療において, 対象となる患者の問題点 を身体, 認知, 精神, 社会各面をアセスメントして, 記 録しておく。医療記録から基本的な情報(診断名, 治療 方針, リハビリテーション目標, 各療法の経過, 社会的
背景など)を把握しておく。

4. 治療目標の設定，治療方法の選択

アセスメントを元に, 園芸療法における治療目標, 実 際の治療方法を選択する。機能レベルに適した治療方法 を選択，場合によっては適応させる工夫する。

\section{5. 園芸療法の実施}

園芸療法を実施する際は，患者の機能レベルを理解 し, 適度な援助, 指導を行う。治療形態は, 個別, 集団 とそれぞれの体系で行われるが, 常に各患者独自の目標 を考慮しながら，治療活動を行っていく。

6. 園芸療法の評価

治療効果を定期的に評価し, 先の治療に反映させて いく。医療, リハビリテーションチームとして, 他職種 との連携をはかり，お互いの治療効果を認識し，全体的 な治療目標到達を目指す。

\section{IV. 園芸療法におけるアセスメント例}

Simons と Strausによる5), 園芸療法に限定したアセスメ ントの例を挙げるが, アセスメントするそれぞれの項目 は，6つの機能段階に分かれ，5が完全自立，4が監視，3 が最小限の援助, 2 が中程度の援助, 1 が最大限の援助, N/Aが測定不可となる。

\section{1. 移動動作}

園芸療法に独立して参加できる，時間通りに園芸療 法に参加できる, 温室内を動き回れる能力。

2. 身体動作

園芸活動を右側で行える, 左側で行える, 両側で行え る，鉢植えを正面に持ってくる，園芸器具を使用でき る, 植物に水遣りができる, 一連の園芸活動を最後まで 終了することができる能力など。

3. 認知機能

口頭, 書面の指示を理解できる, 各指示に従うことが できる, 園芸活動に集中することができる, 園芸療法の 簡単な概念を理解できる, 定期的な園芸療法のスケ ジュールを理解することができるなど。

\section{4. 精神機能}

新しい活動に自ら進んで参加できる，必要な援助を 求めることができる, 自己の活動に自信が持てる, 感情 をコントロールできるなど。

5. 社会機能

他人と関わることができる，グループ活動が行える， 他人と適切に関わることができる, 現実的な自己の身体 能力を自身で理解できるなど。 
これらの機能をアセスメント用紙などを利用して効 果的に理解し, その後の治療計画, 目標に反映させる。

\section{V. 園芸療法の効果}

園芸療法の効果として身体, 認知, 精神, 社会各面の 相乗効果が挙げられている。身体面においては, 園芸療 法を通して, 筋力, 筋持久力, 心肺機能, 巧緻性, 座位 バランスの向上や園芸に必要な各作業能力の向上が挙 げられている。認知面に関しては, 注意力, 集中力の向 上, 学習能力の向上, 記憶力の向上などが挙げられてい る。精神面に関しては, やる気の向上, 抑うつ気分の改 善, 自己尊重感の向上, 感情コントロール力の改善など が挙げられている。また, 園芸療法を通した, ストレス 解消効果も最近では注目されている。社会面では, 園芸 療法をグループで行うことで, 協調性の改善, 対人能力 の改善などがあり, 職業訓練として応用されれば, 園芸 活動を通して, スケジュール管理能力の改善, 植物管理 能力の向上などが期待されている5)。

\section{VI. 実際の園芸療法の例}

ニューヨーク大学病院ラスクリハビリテーション部 門においては, 病院内に植物園が整備され, 園芸療法に 活用されているので，その内容を紹介寸る6)。

\section{1. 入院型心臓リハビリテーションへの応用}

心臓リハビリテーション治療計画の一部として, 入 院時に患者は, 植物園を訪れ, 園芸療法士により, 園芸 活動の身体的恩恵とストレス解消効果について教育を 受ける。植物園の案内を通して, 患者は自己の植物を選 び, 管理方法について説明を受け, 退院後も治療の一環 として，その植物を活用していく。

2. 精神科入院患者一の応用

入院中は病棟からの外出が厳しく制限されている精 神病患者は, 担当医の処方箋により, 植物園一の定時内 での外出が許可される。植物園を訪問中に, 患者は, 選 択した植物の繁殖方法を学習し, 退院時に共に持ち帰っ ていくという, 一連の園芸療法を通して, 自律性を向上 させていく。

3. 地域高齢者への応用

ラスクリハビリテーション部門と地域の社会サービ 又部門が提携して, 地域の高齢者が, 植物園にて, 植物 の管理方法を学習, 習得した後に, 地域にて植物を実際
に植え, 街の景観を向上させる活動を行っている。

4. 認知症を有する高齢者への応用

認知症を有する高齢者に対して, 園芸活動を行うこ とにより, 様々な回想を引き起こし, 感覚, 認知能力, コミュニケーション能力を刺激することを目的として いる。

5. ラスクリハビリテーション部門でのその他の園芸療法 作業療法部門と提携した脳血管障害患者に対して機 能回復を図る園芸療法, 失語症患者に対して社会交流を 促進する園芸療法, 䫏痛を有する患者に対して孤独感を 減少させるための集団園芸療法などが行われている。

同様な園芸療法が，それぞれの臨床場面で, 対象とな る患者のニーズ, 機能レベル, 施設状況により, 様々な 形を取り行われている。

\section{VII. 事 例}

ケースAは認知症を発症し，かつ加齢による身体機能 の低下の為に, 介護施設に入所してきた。入所時に, 移 動能力は, 自ら車椅子を駆動し, ADLも入浴, トイレ動 作以外は，ほぼ自立していた。Mini Mental State Examinationのスコア20で, 認知面で混乱するも場合も あった。周囲との社会的交流を避ける傾向にあり，自室 に閉じこもる時間が多かった。

ケースA は, 過去に園芸を楽しみの活動として行って いたというので, 週に一回, 園芸療法として, 施設内の 食堂にある植物の刚り込みを行う指導をした。普段は, 植物は, 食堂の空際に設置されているが, 園芸療法の際 には, 食堂のテーブルに植物を移動し, 刈り込みを行う ように指導した。当初は, 食堂のテーブルに植物を移動 させる動作に介助を要したが, 膝の上にバランス良く植 物を置きながら, 車椅子移動する訓練を行った結果, ケースA自身で, 植物を移動させる動作が可能となった。

当初は, 週に一回の園芸療法スケジュールをケースA が忘れてしまうこともあったが, 園芸療法士の介入を通 して, 園芸療法開始後, 3週目には必ず決まった時間に, 植物の刈り込みを実施するようになった。

ケースAは, 現在では, 週に1回の刈り込み作業に加 え, 週に3回の植物に水を与える作業を始めている。4週 間の園芸療法を継続するに連れ, 混乱する状況が減少 し, 周囲とも関わりを持ち始め, 社会活動が広がってい る。日常活動としても, 精神的恩恵, 移動能力, ADL能 力を維持させるためにも, 園芸療法を楽しみにしている。 




Medical Center Rusk Instituteの植物園

\section{VIII. 研究例}

園芸療法は注目を集めている一方, 体系化した治療 として，まだまだ発展の段階であるが，2005年に発表さ れた園芸療法に関する研究を紹介寸る。

1. 入院心臓リハビリテーション患者の気分と心拍数への 園芸療法の影響7)

ニューヨーク大学医学部心臓リハビリテーション部 門によって行われた心臟リハビリテーション入院患者 に, 園芸療法の身体と精神的効果を検証した研究であ る。107人の心臟リハビリテーション入院患者に対して, 約半数が園芸療法を行い, 他の半数が, 患者教育クラス に参加した。2つのグループともそれぞれの介入前と後 で, Profile of Mood States（POMS）にて気分の具合を測 定し，パルスオキシメーターにて心拍数を測定したが, 園芸療法を受けたグループの介入前後の変化は, 有意に POMSによる気分の具合が良くなり, 心拍数も減少した。 一方で, 患者教育クラスに参加したグループは, 介入前 後のPOMS と心拍数の変化が見られなかった。この結果 は, 園芸療法が，心臓リハビリテーションにて効果的な 介入である可能性を示唆した。

\section{IX. 終わりに}

園芸療法は様々な形態を取りながら,の医療現場で, 効果的な治療方法として活用されている。筆者も，様々 な重度の疾病, 障害を抱える高齢患者に対して, 勤務施 設にTherapeutic Gardenを活用しつつ, 積極的に園芸療法 的な介入をしている。一方で, 園芸療法に関する研究は まだまだ少なく,これから更なる園芸療法の効果が実証

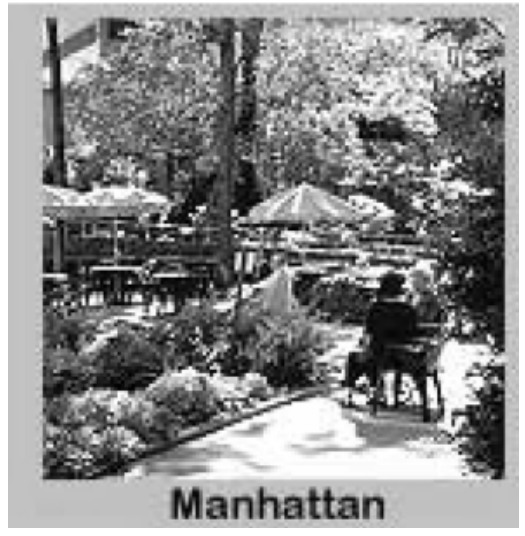

写真3 Jewish Home and Hospitalの Therapeutic Garden



写真4 園芸療法の一場面

が必要であるが, 各医療関係者が積極的に園芸療法を取 り入れて頂く事を願っている。

\section{引用文献}

1) The American Horticultural Therapy Association (AHTA). http:// www.ahta.org/information/（閲覽日2006年12月1日）。

2) Thomas CC: Horticulture for the disabled and disadvantaged. Bannerstone House, USA, 1978, p9.

3) The New York Botanical Garden. http://www.nybg.org/edu/(閲覧 日2006年12月1日).

4) Relf D: Horticulture: A Therapeutic Tool. http://www.hort.vt.edu/ human/ht5a.html（閲覧日2006年12月1日).

5) Simon P, Straus CM: Horticulture as therapy. Principles and practice. Haworth Press, USA, 1998, pp94-96

6) Rusk Institute of Rehabilitation Medicine. http://www.med.nyu. edu/rusk/glassgardens/therapy/adults.html（閲覧日2006年12月 1 日)。

7) Wichrowski M, Whiteson J, Haas F, et al.: Effects of horticultural therapy on mood and heart rate in patients participating in an inpatient cardiopulmonary rehabilitation program. J Cardiopulm Rehabil, 2005, 25(5): 270-274. 